\title{
THE SOCIOLOGY OF NETWORK CAPITAL. ON THE BOOK OF ENDRE SIK: A KAPCSOLATI TŐKE SZOCIOLÓGIÁJA (EÖTVÖS K., BUDAPEST, 2012)
}

KINGA SZÉKELYl

Endre Sik is a contemporary Hungarian sociologist, a professor emeritus, at Eötvös Loránd University Department of Minority Studies, and senior research fellow at the TÁRKI Social Research Institute.

His main research fields are the sociology of migration, labor-market sociology, the sociology of informal economy, and network capital.

Endre Sik's book, entitled A kapcsolati töke szociológiája, was published in 2012 in Budapest in Hungarian. The English title of the book should be 'The Sociology of Network Capital'.

Beginning in the 1980s, Sik concentrated both directly and indirectly on studying the function of networks and their effect on society by examining reciprocal labor-exchanges between households and mutual self-help building efforts, or 'work bees'.

In the middle of the 1990s he declared that the expression 'social capital' was not being properly used in the literature (see Sik, 1994)2, coinciding with the argumentation of Angelusz and Tardos (see Angelusz - Tardos 1998) ${ }^{3}$. Whilst latter authors promoted the term 'social network resources' in the literature - because it seemed to be more neutral - the formerly-mentioned author, Sik, preferred the use of the term 'network capital' instead of 'social capital'.

1 Kinga Székely is a Ph.D. student at the Corvinus University of Budapest; e-mail: szkinga2003@ gmail.com

2 Sik, Endre (1994) Network capital in Capitalist, Communist and Post-Communist Societies. International Contributions to Labor Studies, 1994, Vol. 4., pp. 73-93.

3 Angelusz, Róbert - Tardos, Róbert (1998), A kapcsolathálózati erőforrások átrendeződésének tendenciái a kilencvenes években. In Kolosi Tamás, Tóth István György, Vukovich György (eds): Társadalmi riport 1988. TÁRKI, Budapest, 237-254. 
During the 1990s the focus of Sik was increasingly on interpreting economic activities and more towards a reflexive analysis of the network capital of the politics of the former regime. The book under description is based on the results of previously-published essays and studies of the author which are strongly related to the topic of network capital.

The general purpose of the book is to describe the role of network capital in various forms of economic institutions (kinship, community, workplace, networks of occupational types) and its effect on political action using examples from the communist era and from the transitional period of Hungary in order to support path-dependency theory. The author applies a critical approach regarding the concept of 'social capital' in order to highlight the complexity of the term 'social capital' and to formulate the need for decomposition of the term. He suggests employing the term network capital in the study of a particular form of social capital; namely, networks. Another goal of this book is to emphasize the existence of the negative effects of network capital as well as positive ones.

The book has seven chapters. The first chapter presents a discussion about the decomposition of social capital. The second chapter takes as its focus the beneficial forms of network capital in the form of work exchanges between households. The third chapter details the importance of network capital in the labor market. The next chapter describes a specific Hungarian case of when network capital became revaluated in the case of a specific type of occupation - taxi driving - in a special economic situation. The fifth and the sixth chapters offer an analysis of the effect of network capital on political action, presented through a case study of the network(ing) of the politician György Aczél during the communist era, emphasizing the inheritance of this network on post-communism. The seventh chapter brings together the findings of the previous chapters and uses them as an explanation to support path-dependency theory.

In the first chapter of the book Sik presents in the form of a literature review a problematization of the term 'social capital'. The critical approach opens by avoiding the term 'social capital' (társadalmi töke), instead he decides on using the term 'network capital' (kapcsolati töke). The author formulates the problem that the definitions applied in the literature refer to very different components of the term 'social capital', such as networks, trust, norms, civic participation, etc. The problem lies with the fact that there is no common definition that involves all of the components and which also describes the relationship between the components. The first thesis is that this situation may lead to the under- or overvaluation of embeddedness. Accordingly, the author emphasizes the importance of extracting the phenomenon network 
capital from the term 'social capital' and creating several subcategories of social capital. He argues that mapping and describing subcategories of social capital is unavoidable and beneficial to understand better 'social capital'. Sik offers examples for subcategories using the literature such as 'ethnic capital', 'cultural capital', 'institutional capital', and 'civil capital', etc. He makes decisions about the consistent use of the term 'network capital'. Particular emphasis is placed by the author on how 'network capital' is strongly influenced by social relations (and thus by culture), and for which purposes.

From the second through to the fifth chapter the author concentrates on presenting purposes for what networks are used, and on describing the effects of network capital on economic activities and their results.

In the second chapter, labor exchange between households is the topic of discussion. The thesis of this chapter is that the use of network capital is an alternative solution in a situation of constraint when there are no other alternatives. Sik uses the example of "kaláka" or, in English, mutual aid in self-help building (an expression used by Sik, 2010) ${ }^{4}$, which is based on kinship and community networks (involving relatives, locals, and rarely friends). The motivation for using mutual aid in self-help building, according to the author, is workforce shortage in a household, or a response to unforeseen difficulty, such as when a household cannot cope with a situation, thus involves a situation of constraint. The impact of mutual aid on a household through self-help building affects positively the housing problem at a societal level by decreasing the lack of housing. Sik emphasizes the negative effect of the different forms of network capital as well: he states that mutual aid in self-help building involves retaliation liabilities which can increase the tension in networks through misunderstandings, forgetting, or revalutions of opportunities. Related to the inheritance of mutual work exchanges between households, he finds that, after the systemic change in Hungary, these exchanges did not disappear, but their form changed together with the needs; more specifically, from a demand for house building and child care help to a need for help with household work and agricultural work. Sik argues that when alternative solutions are scarce in uncertain and constraint situations, the value of networks increases, thus inter-household exchanges are important in times of crisis for reducing uncertainties, but this situation may have negative effects as well.

The third chapter describes the use of network capital in Hungary in the 1970s in the professional, agricultural environment and in terms of

4 Sik, Endre (2010) Network capital dependent path-dependency. Corvinus Journal of Sociology and Social Policy, Vol. 1 (2010) 1, 77-102. 
cooperation between local governments and settlements. The thesis presented in this chapter is the use of network capital is an alternative solution to cope with uncertainty when there are no other alternatives. Here, I present several examples.

Sik notes that network capital is important in many cases. At first he presents the case of migrants and the importance of "migration shell' ("migrációs burok"). In this case, network capital is used in situations of constraint in order to reduce the costs of information gathering, searching, and uncertainty.

Sík offers other examples at both levels at individual and at organizational level as well. At individual level, Sik presents some individual-level cases concerning the dense inter-personal networks of social scientists built on casual work in the scientific environment in the 1970s. Sik argues that the labor market for social scientists was networked during this period. Since the only (legal) employer was the state, the majority of people worked in state institutions, thus casual workplaces were created in this environment where infrastructure (e.g. professionals, working hours, materials) was made accessible for individuals to make a private profit. Sik finds that causal jobs were made available by a supervisor and involved at first modern primary relations (i.e. colleagues), but were then extended to traditional primary relations as well because of labor shortages. This situation created a loose and flexible network with long-term personal relationships, with an assumption of mutual inter-dependency and frequent changes in network elements. According to Sik, this means that labor networks are embedded in the general system of interpersonal relationships and these systems are mutually reinforcing, thus increasing the inertia of both systems. The potentially negative effects of this are generated by operating mechanisms which are based on rumors.

At an organizational level, he presents details about the personalized interorganizational exchanges that existed in the case of agricultural cooperatives. Sik argues that the general motivation behind this form of cooperation was a lack of infrastructure, and thus necessity (through a lack of tools or fuel) or emergency situations. Sik offers another example; personalized interorganizational exchanges between local governments (inside and outside the country), in which he finds that cooperation between local governments was partly motivated during socialist times by cultural and economic factors, although after the transition cooperation was solely based on cultural factors (tradition, education, language, co-operation; the observations are made for the situation as it existed until the 2000s).

Reflecting on the thesis applied in this chapter the author presents support for that network capital is an alternative solution in a situation of constraint. In case of migration constraints are lack of information and high costs. In 
case of the causal work of social scientists is presented that, the constraints involved are lack of human resources. In case of inter-organizational exchange constraints are lack of tools and fuels, amongst other things. Can we find constraints in the last case, such as a lack of interaction with neighboring countries? If so, then we must see that constraints may be very diverse in nature.

With respect to the dual effect of network capital, such as positive and negative effects, Sik's argument is partially confirmed. While in case of the causal work of social scientists the author presents a negative effect of network capital, such as rumors, until the negative effects are missing in case of both examples presenting the inter-organizational exchanges. Therefore, the argumentation about the existence of the dual effects of network capital in this case is weak.

In the fourth chapter the author focuses on the use of network capital by one occupational type in the economy of the early 1990s. The type is taxi cab drivers in Hungary and their special situation which was influenced by the subculture of taxi drivers and by a sequence of events wherein the role of networks was revaluated.

Sík borrows the occupational typology of G. Mars (1983) . Mars created four categories, and symbolized them using the names of animals: the hawk is the symbol of an independent and individualistic entrepreneur; the donkey represents a subordinated and isolated wage earner in a fixed job; a wolf works and earns in a group with which he has long-standing personal ties and strong solidarity, while vultures find prey on an individual basis, but there exists a loose informal network which can be quickly activated that supports their activities.

Sík argues that taxi cab drivers are 'vultures' and that their occupation is a subculture because it involves special norms and a code of conduct. The 'vulture' attitude means that members fight for their existence against calamity because their economic being depends on it. The activity of taxi drivers is individual and autonomous yet involves a loose 'inter-vulture' network, according to Sik. Taxi drivers as a group has a solidary subculture because of their endangered occupation. In times of crisis they can mobilize this network. The author formulates two theses in this chapter. The first is that drivers, because of their vulture attitudes, were rebels (by creating a blockade in the capital to protest against increases in the price of gasoline). The other statement claims that Hungarian taxi drivers chose the blockade as a protest form because they were confused and afraid of calamity arising from the price

5 Mars, Gerald (1983) Cheats at work. Allen and Unwin, London. 
increases which they believed would lead to a crisis for them. They were thus endangered not only as customers, but as producers as well through the threat of job losses. The chosen protest form - the blockade - resulted in a shortterm success (the price increase was postponed). Sik argues that the network and the subculture of taxi drivers several years after this event still existed, but had changed.

This example and its argumentation shows that network capital can be a powerful tool in an emergency situation if a loose and a solidary network exists which can be mobilized. Thus, through the case of taxi cab drivers it is presented (only) the positive effect of network capital, which is mobilized in endangered situation.

The following two chapters describe the role of network capital in political action in the case of Hungary during socialism and post-socialism. Sik creates a typology which involves ideal types - on the one hand, 'network-sensitive', and on the other, 'network-insensitive' societies - in order to support his claim about the path-dependency of Hungarian society. Network-sensitivity means that networks are the only accessible resources in society and are the first options for solving everyday problems, anticipating other solutions such as legal or formal solutions, but raising the likelihood of corruption and bribery. In network-insensitive societies network capital plays also an important role, but is not dominant; it rather plays an auxiliary role.

In the fifth chapter the author formulates the following assumption in relation to Hungarian society: networks built during communism are selfsupporting, but even if they (the networks) cease to exist, the networksensitive culture survives. The importance of networks involves two features. At first, Sik refers to the dysfunction of the market, which means that networks are awarded prominent roles and thus have a corrective function. Secondly, according to the author, the importance of networks in communist societies lay in the structure of the system (the fight against shortages), so they were system specific. Sik argues that the informal or secondary economy is network-intensive and supported by a system of barter-relationships (the best solution for overcoming various types of difficulties during production), bribery and the offering and accepting of 'tips' (in the case of a consumption shortage), but in politics as well network capital plays an important role. Sik provides a Hungarian case study and argues that the importance of networks increases in societies where political oppression exists and where is great uncertainty because of the exclusion of the public from the exercise of political power. Aczél, György the politician is considered a 'network capitalist' by the author. His ability to mobilize networks was discovered by Kádár, János. Aczél himself recognized that politics is network-sensitive and understood 
the importance of networks in general. As a result he created the 'Aczélnetwork' ('Aczélháló'). During networking, institutional relationships become personalized and personal relationships breach organizational borders. The latter resulted that important decisions - such as nominations for jobs - were made at informal meetings; an occurrence which contributes to the emergence of favoritism and/or nepotism, what is considered the negative effect of network capital. Sik emphasizes that gossip or "unofficial publicity" (Sík, $2010)^{6}$ damages generalized trust which results in the flourishing of particular trust. Sik concludes that the spread of networks and the spread of attitudes about how and for what purpose networks could be used strengthened the network-sensitive culture and increased the expected utility of investments into networks in both political and business life in Hungary during times of socialism.

In the sixth chapter the author takes as his focus post-socialist Hungary. Sik assumes that the 'Aczél-network' survived (i.e. that network-sensitivity survived the transition) and that this phenomenon supported the inertia of networks and institutional non-change. Sik brings data to bear to support the proposition that traditional family-centric network capital was still strong in post-communist Hungary in the 1990s (see Angelusz - Tardos 1998) ${ }^{7}$. Another proposition of Sik's in relation to the use of network capital relates to trust. He argues that, in transition countries, generalized trust and particularistic trust operate similarly to during the communist era when particular trust was high and generalized trust was low. This line of argumentation relates to an important discussion regarding the composition of social capital in Europe by Pichler and Wallace (see Pichler and Wallace 2007) ${ }^{8}$ based on empirical data from Eurobarometer (2007).

The aforementioned authors differentiated between two forms of social capital: informal and formal ones. Formal social capital includes participation in civil society, and generalized trust. Informal social capital is composed of the informal bonds between people as an investment in social relations with expected returns, or as an affective tie or friendship and through particularistic

6 Sik, Endre (2010) Network capital dependent path-dependency. Corvinus Journal of Sociology and Social Policy, Vol. 1: 1, 77-102.

7 Angelusz, Róbert - Tardos, Róbert (1998) A kapcsolathálózati erőforrások átrendeződésének tendenciái a kilencvenes években. In Kolosi Tamás, Tóth István György, Vukovich György (eds): Társadalmi riport 1998. TÁRKI, Budapest, 237-254.

8 Pichler, Florian - Wallace, Claire (2007) Patterns of Formal and Informal Social Capital in Europe. European Sociological Review, Vol.23, Number 4 (2007), pp. 423-435, Source: www. esr.oxfordjournals.org, Downloaded: October 20th, 2013. 
trust is tied to particular people or a specific social group. The authors state that, in the Scandinavian countries and in the Netherlands, they could identify both forms of social capital, while in East and South Europe they found an imbalance between formal and informal social capital in which informal social capital substituted formal social capital. Sik draws similar conclusions as concerns Hungary where particularistic trust blossoms and generalized trust is inhibited: a legacy of communist times.

In a political context the cause lies in the fact that during the transition the newly-created parties did not have enough time to prepare their (inexperienced) cadres because the political transition was quick and unforeseen; accordingly, these parties recruited through their peer groups, friends, and kinships (see Czakó - Sik 1995) . The result is that network-sensitivity survives in politics and has created a path-dependent capitalism, argues Sik.

To summarize the findings and conclusions regarding the general purpose of the book, I find that the examples presented by the author are vivid and are rooted in the same proposition: the use of network capital is a solution in a situation of constraint when there are no (formal or legal) alternatives. This applies in times when there are shortages of labor, infrastructure (a lack of tools or fuel) in households or (casual) workplaces, or in response to emergency situations in order to reduce the cost of information gathering, searching, and to cope with uncertainty and crisis. One exception is perhaps the example of inter-organizational exchanges between local governments (inside and outside the country), where Sik found that cooperation between local governments was motivated during socialism by cultural and economic factors, but after the transition merely by cultural factors.

How and for what purpose 'network capital' is used is strongly influenced by social relations and by culture. This claim is well supported in the example of taxi cab drivers who have a solidary-based subculture with special norms and codes of conduct and a loose 'inter-vulture' network which can be mobilized in case of crisis. The creation of loose networks or long-term personal relationships (assuming mutual interdependency and frequent changes in network elements) are necessary responses to situations of economic constraint.

Furthermore, the importance of networks increases in societies in which political oppression exists along with great uncertainty due to the exclusion of public sphere from the exercise of political power. During networking, institutional relationships get personalized and personal relationships

9 Czakó, Ágnes - Sik, Endre (1995) A hálózati tőke szerepe Magyarországon a rendszerváltás elött és után. 2000, 7: 3-12. 
penetrate organizational borders. The importance of networks in Hungarian communist society was derived from the structure of the system (the fight against shortages). But in times of transition household exchanges did not disappear, but rather their form changed as needs changed: traditional familycentric networks are still important.

The following processes are described by Sik as maintaining the conditions for network-sensitivity in post-communist Hungary: the socialization of a population rooted in socialism, money shortages during times of transition, the dependency of privatization processes on personal relationships, an informal economy built on networks, the greater importance awarded to kinship in comparison with western cultures, labor networks embedded in the general system of interpersonal relationships and the importance of particularistic trust in sharing information. In a political context according to him the causes of institutional non-change are rooted in the fact that during the transition newly-created parties did not have enough time to prepare their (inexperienced) cadres because the political transition was rapid and unexpected. As a result, these parties recruited through their peer groups, friends, and kinships (see Czakó - Sik 1995). Sik concludes that Hungarian path-dependency is dependent through its culture of networks, specifically through the systems of norms and institutions which define the conditions of use of personal relationships. This is how network-sensitivity has survived in politics; and it is present in the economy as well; and has created pathdependent capitalism.

Sík worded that in general, primarily relying on network capital raises the likelihood of corruption and bribery in economic and political settings in Hungary. Reflecting on the goal of this book, which is to emphasize the dual effect of network capital, through presenting the negative effects of network capital alongside positive effects, little support (such as the existence of tension in networks) is found in the case of household exchanges (mutual aid in selfhelp building). In institutional settings such as casual work in workplaces, rumors may have negative effects. In case of inter-organizational exchanges, the argument about the existence of the negative effects of network capital was missing, thus this argument was partially confirmed. According to Sik change will happen when other resources become more accessible and when other solutions are found to be more beneficial than using network capital. Until then, network dependent path-dependency will survive, according to the author.

The general goal of the book was reached through its presentation of the role of network capital in the various forms of economic institutions (kinship, community, workplaces and networks of occupational types). Related to the 
goal of this book, which is to emphasize the dual effect of network capital, little support was found for its negative effects in the case of presented concrete examples from communist and post-communist Hungary. The theoretical discussion about the path-dependency of Hungarian society is supported using a description of ideal types of network-sensitive and network insensitive societies. Sik, based on these ideal types, argues that Hungarian society is a network-sensitive society whose networks are the only accessible resources (he offers examples of when constraint is the starting point for activity), and the first choice for solving everyday problems, anticipating other solutions such as legal or formal solutions. This situation contrasts with that which exists in societies where network capital plays an auxiliary role. The reader may decide if he/she can accept this argumentation based on ideal types. I think that involving the empirical findings of Pichler and Wallace (2007) (or others) in the discussion would increase the stability of the argumentation; without these contributions, Sik's theoretical discussion is weakened.

This book is an important contribution to the literature of economic sociology in Hungary through its collection and presentation of examples about the role and effects of network capital in a political and economic environment, making comparative analysis of two time-periods - communism and post-communism -, using specifically Hungarian examples. This book may also have a great impact on economic sociology more generally by offering support for the propositions that economic action as well as political action is embedded in social relations. 